\title{
Impact of Foreign Direct Investment (Fdi) On the Stock Market Performances in Nigeria (1985-2014)
}

\author{
Omodero, Cordelia Onyinyechi ${ }^{1} \&$ M.C. Ekwe ${ }^{1}$ \\ ${ }^{1}$ Department of Accounting, Michael Okpara University of Agriculture, Umudike, P.M.B. 7267 Umuahia, Abia State, \\ Nigeria. \\ Correspondence: Omodero, Cordelia Onyinyechi, Department of Accounting, Michael Okpara University of Agriculture, \\ Umudike, P.M.B. 7267 Umuahia, Abia State, Nigeria.
}

Received: September 12, 2016

Accepted: October 5, 2016

Available online: October 19, 2016

doi:10.11114/afa.v3i1.1932

URL: http://dx.doi.org/10.11114/afa.v3i1.1932

\begin{abstract}
The study examined the impact of Foreign Direct Investment (FDI) on the stock market performances in Nigeria, from 1985 - 2014. The secondary data used were collected from IMF, International Financial Statistics (2015), CBN Statistical Books (2015). Multiple regression of least square estimation was the tool used to analyze the data in this study. In the model, the FDI was regressed on RGDP, Consumer Price Index, Real effective exchange rate, Money supply (M2), Share price index, Treasury bill, Nigerian stock exchange transactions. The study revealed that FDI has an insignificant and negative impact on the economy and the macroeconomic variables that determine the performances of the Nigerian stock market. The paper therefore recommends policies that would encourage foreign firms operating in the oil and gas including the telecommunication and agricultural sectors to be listed since it would go a long way in attracting more FDI, leading to improvement in the stock market performances.
\end{abstract}

Keywords: Foreign Direct Investment (FDI), Stock Market performance, Macroeconomic variables, real effective exchange rate, Money Supply, Nigeria.

\section{Introduction}

Foreign Direct Investment are the net inflows of investment to acquire a lasting management interest (10 percent or more of voting stock) in an enterprise operating in an economy other than that of the investor. It is the sum of equity capital, reinvestment of earnings, other long-term capital, and short-term capital as shown in the balance of payments. This series shows net outflows of investment from the reporting economy to the rest of the world and is divided by GDP (International Monetary Fund, International Financial Statistics and Balance of Payments databases, World Bank, International Debt Statistics, and World Bank and OECD GDP estimates). FDI is an investment made by a company or entity based in one country, into a company or entity based in another country. FDI differ substantially from indirect investments such as portfolio flows, wherein overseas institutions invest in equities listed on a nation's stock exchange. Entities making direct investments typically have a significant degree of influence and control over the company into which the investment is made (Investopedia). Financial markets, and especially stock markets, have grown considerably in developed and developing countries over the last two decades this is as a result of rapid financial and political transformation. To increase their share of FDI flows, most of the countries easy restrictions on FDI, strengthened macro stability, privatization of state-owned enterprises, domestic financial reforms, capital account liberalization, tax incentives and subsidies have been instituted. For many emerging countries, the best policy will involve continuing the establishment of sound fundamentals and attracting FDI, but not necessarily the trading or even listing of securities locally. In addition, stock markets have been established to intermediate funds towards investment projects. Stock Market Performance is affected by a wide array of factors such as economic, political, international, and company-specific issues. When it comes to the overall index performance then the domestic economy's National Income, GNP (Gross National Product) growth, PPP (Purchasing Power Parity), Monetary issues, Political Stability, International Relations, Balance-of-Payment situation, etc. comes into consideration. But when it zeros down to the specific stocks then the company specific information (profitability, sales, profit margin, growth, etc.) play important role in the price determination of the stock. When the stock prices and the index movements show positive trend (that is, upward movement) then we call that the stock market performance are bullish. We call an investor to be bullish when his perceptions about the market and the economy are positive, i.e., he is expecting further rise in prices, and consequently 
is in the buying spree.

Some of the factors which boosts up the market are good present or projected economic growth of the economy, positive monetary outlook of the apex bank, decrease in fiscal deficit, good performance of a company in terms of profit, sales, etc. But when the general perception of the investors is negative then the stock market also declines showing a bearish trend. When a person is not confident enough to buy stocks because of his negative expectations from the economy and sells off stocks then he is known as an investor with Bearish perceptions.

If the performance of an economy is good then the Stock Market Performance is also good and bull markets are inevitable. Performance of an index (or a stock) might exceed that of the actual performance of the economy (or a company) because the expectations of the investors might cross the actual performance of the same. Thus Bull Run encounters correction of indexes or stocks from time-to-time, which is actually a healthy sign. If the economic performances are not up to the mark then the stock market is most likely to underperform and might see a downward trend. This downward movement of the market is known as Bearish Market. Bullish/bearish market may sustain for weeks or months with temporary rally known as secondary trend (or short term). When bullish/bearish market runs continue from 5 to 20 years with occasional corrections then it is known as Secular Trend (Long Term). Hence, overall economic and stock specific performance influences performance of the market. Thus, Stock Market Performance acts as the barometer of the economy as a whole (Economy Watch, 2010).

During the 1990s, the composition of capital flows changed dramatically, with bank lending being replaced mostly by foreign direct investment (FDI) and then by portfolio investment. Bank lending declined from 70percent of net private capital flows in the 1970s to about 20 percent in the 1990s. While FDI constitutes the largest share of capital flows (around 50 percent), portfolio investment (bonds and equity) has also increased substantially, accounting for about 30 percent of total capital flows in the 1990s. In absolute values, bond and equity flows excluding those counted as FDI-increased from $\$ 1$ billion in 1990 to $\$ 40$ billion in 1996, with bond flows exceeding equity flows in developed economy since 1994.

FDI inflows in 2006 were 38\% higher than in 2005, approaching the peak of $\$ 1,411$ billion reached in 2000. Although FDI flows to all three major country groups rose, they varied greatly among regions and countries. FDI flows to developed countries in 2006 rose by $45 \%$, well over the growth rates of the previous two years, to reach $\$ 857$ billion. The continued rise in FDI flows across regions largely reflects strong economic growth and performance in many parts of the world. High corporate profits (and stock prices) boosted the value of cross-border M\&As, which account for a large share of such flows. The number of Greenfield and expansion investment projects increased by $13 \%$ to 11,800 projects, notably in developing countries and in the services sector. Thus, as in more recent years, FDI flows continued to be the most important and stable source of external financing for developing countries.

\section{Objectives of the Study}

The main objectives of this research is to investigate the impact of FDI on the Stock Market Performances in Nigeria, (1985-2014). The study also seeks to achieve the following objectives:

1. To assess the extent to which FDI affects the economic growth which is represented by RGDP;

2. To determine the FDI effect on the Nigerian Stock Exchange Transactions, Treasury Bills, Share Price Index;

3. To evaluate the extent to which Money Supply (M2) is affected by FDI;

4. To assess the gross impact of FDI on prices of goods and services proxy by CPI;

5. To determine the effect of FDI on the exchange rate.

\section{Research Questions}

To achieve the above objectives, the following research questions have been raised:

1. To what extent does the FDI affect the economic growth which is represented by RGDP?

2. To what extent have the Nigerian Stock Exchange Transactions, Treasury Bills, Share Price Index been affected by the FDI?

3. To what extent has Money Supply (M2) been affected by FDI?

4. To what extent does FDI affect the prices of goods and services?

5. To what extent has FDI affected the exchange rate?

\section{Research Hypotheses}

Ho1: There is no significant relationship between the FDI and the economic growth in Nigeria.

Ho2: No significant relationship exists between the FDI Nigerian Stock Exchange Transactions. 
Ho3: No significant relationship exists between the FDI and the Treasury Bills.

Ho4: There is no significant relationship between the FDI and Share Price Index.

Ho5: No relationship exists between Money supply (M2) and FDI.

Ho6: There is no relationship between FDI and the prices of goods and services.

Ho7: No tangible relationship between Exchange rate and FDI.

\section{Literature Review}

\subsection{Conceptual Definitions}

Foreign Direct Investment (FDI) is an investment made by a company or entity based in one country, into a company or entity based in another country.

Stock Market "is the market in which shares of publicly held companies are issued and traded either through exchanges or over-the-counter market. Also known as the equity market, the stock market is one of the most vital components of a free-market economy, as it provides companies with access to capital in exchange for giving investors a slice of ownership in the company. The stock market makes it possible to grow small initial sums of money into large ones, and to become wealthy without taking the risk of starting a business or making the sacrifices that often accompany a high-paying career" (Investopedia).

Stock Exchange "is a place, whether physical or electronic, where stocks, bonds and/or derivatives in listed companies are bought and sold. A stock exchange may be a private company, a non-profit, or a publicly-traded company (some exchanges have shares that traded on their own floors)" (Farlex Financial Dictionary, 2012).

Stock Market Performance "is the indicator of the stock market as a whole or of a specific stock. It gives signal to the investors about their future moves. The movement in the price of a stock and the indexes gives the idea of the near future trend of the stock, sector or the economy as a whole. As financial domain is the most important one of an economy, so the stock market performance works as an indicator of the overall health of the economy" (Economy Watch).

Stock Market Index "is a measurement of the value of a section of the stock market. It is computed from the prices of selected stocks (typically a weighted average). It is a tool used by investors and financial managers to describe the market, and to compare the return on specific investments" (Wikipedia). It typically gives the overall performance of the market or of a specific sector. Indexes reflect the performance of the economy or a sector in entirety. Stock Prices are an indicator of the performance of the stock. If the price of a particular stock is rising then it is perceived that it has certain positive news or signals. But, if it decreases then there must be some news regarding its performance, which is generating negative signals to the market. Hence, the stock price movement and index movements show the general economic trend of a country.

Real effective exchange rate "is the nominal effective exchange rate (a measure of the value of a currency against a weighted average of several foreign currencies) divided by a price deflator or index of costs" (International Monetary Fund, International Financial Statistics, 2015).

Consumer price index "reflects changes in the cost to the average consumer of acquiring a basket of goods and services that may be fixed or changed at specified intervals, such as yearly" (International Monetary Fund, International Financial Statistics and data files).

Real Gross Domestic Product used "is the growth on an annual basis adjusted for inflation and expressed as a percent" (CIA World Fact book, 2015).

Money and quasi money comprise the sum of currency outside banks, demand deposits other than those of the central government, and the time, savings, and foreign currency deposits of resident sectors other than the central government. This definition of money supply is frequently called M2; it corresponds to lines 34 and 35 in the International Monetary Fund's (IMF) International Financial Statistics (IFS) (International Monetary Fund, International Financial Statistics and data files).

Treasury bill "is a short term debt obligation backed by the government with a maturity of less than one year" (Investopedia). The Treasury bill rate is the rate at which a bill is quoted in the secondary market and is based on the par value, amount of the discount and 360-day year (US DEPARTMENT OF THE TREASURY).

Share price index "is a figure based on the current market price of a certain group of shares on a stock exchange" (Web Finance Inc., 2015).

The Nigerian Stock Exchange provides the only trading floor to transact in stocks in the Nigerian capital market. It was set up in 1960 as the Lagos Stock Exchange, a private sector entity, it metamorphosed into the Nigerian Stock Exchange 
in 1977.

\subsection{Theoretical Framework}

The following theories based on an imperfect market situation have been found useful for the purpose of this study.

\subsubsection{Monopolistic Power Theory}

Kindleberger (1969) elaborated on the work of Hymer, by postulating a theory of FDI which is based on monopolistic power. He maintained that Multinational Companies could enjoy the benefit of monopolistic power in an imperfect market situation since they are more advanced in technology possess better managerial skill, they will be in the position to exploit the business opportunity and make as much profit as they wish. However, these advantages are only possible if only their operations are allowed by the host country's policy. Furthermore, for the purpose of national interest and safety of the environment, the host Government might not be willing to allow foreign companies to operate and have the monopolistic power advantage.

\subsubsection{Exchange Rates Theory}

Aliber (1970) found this theory by attempting to explain Foreign Direct Investment as a function of exchange rates interactions. His theory which is based on the strength of various currencies (both the host and the investing countries) states that the countries with stronger currencies can take advantage of the countries with weaker currencies when it comes to exchange differences in a market capitalization. Albert hypothesis was tested with FDI in the US, UK and Canada and the result was positive which confirmed the exchange rate theory.

\subsubsection{Product Life Cycle Theory}

Vernon (1966) developed the product life cycle theory to illustrate the four stages of production cycle in FDI. He identified them as follows: innovation stage, growth stage, maturity stage, decline stage. The study he carried out on US companies FDI in Western Europe after the Second World War in manufacturing firms revealed that US companies took advantage of the new technologies introduced. They enjoyed the growth and maturity stage from $1950-1970$ until the European firms began imitating their products. The competition became so high that the American companies were struggling to maintain a reasonable share in the local markets.

\subsubsection{Internalisation Theory}

Buckley and Casson (1976) discovered this theory which shows that multinational companies organize their internal activities in such a manner that they can benefit from opportunities before them to exploit. They strongly believe in this theory that FDI can lead to profit maximization by firms in an imperfect market situation.

\subsection{Empirical Literature}

Empirical evidences are bound on the impact of FDI on Nigerian stock market performances.

Adam and Tweneboah (2008) examined macroeconomic factors and stock market movement in Ghana using quarterly data from 1991 to 2007. They investigated both the long-run and short-run dynamic relationships between the stock market index and the economic variables-inward foreign direct investment, Treasury bill rate, consumer price index, average oil prices and exchange rates using co-integration test, Vector Error Correction Model (VECM). The study revealed that inflows from FDI in developing countries could bring about technological and economic development, employment opportunities and increase in the production of goods and services. The researchers pointed out that FDI inflows enhance economic growth and improve stock market performance as share price increase was noticed in the trend of data being examined. The study showed that open access to Ghana domestic stock market by foreign investors increased FDI inflows which became a major determinant for share price increase in Ghana stock market.

Abel and Nikki (2011) investigated the impact of financial development, macroeconomic and institutional factors on the flow of foreign direct investments to the Sub-Saharan African region. Panel data from 1995 to 2008 were drawn from 30 Sub-Saharan African countries. The study revealed that financial development, the countries' market size, and corruption among others adversely affect FDI in the region. That means, the absence of infrastructure, trade openness and financial development discourage foreign direct investment in the region.

Oseni and Enilolobo (2011) examined the effect of FDI and stock market development on economic growth in Nigeria from 1980 to 2009. Econometric techniques such as Unit root test, co-integration and error correction mechanism were the statistical tools for data analysis. The result showed cyclical movement for both the FDI and stock market development. The study also revealed that lagged exchange rate could have positive effect on growth.

Okwuchukwu (2015) studied the impact of exchange rate volatility, stock market performance and foreign direct investment in Nigeria. Ordinary least square technique was used to analyse the data. The result showed a significant negative effect on FDI inflow to Nigeria. It was concluded that a stable and well developed capital market will attract FDI to Nigeria. 
Corrado and Jordan (2002) referred to the study of Aje and Daferighe (2009). Their investigation confirmed that stock prices are being affected by factors such as company profits, political factors, and economic performance, interest rates, inflationary rate, real GDP, and taxes. Investment in the stock market is long-term in nature; political and economic instability in a country usually have negative and destructive impact on the stock market performance. In recent times, the Nigerian market have witnessed a serious decline in share prices. The reasons mentioned above could be responsible.

Asaolu and Ogunmuyiwa (2011) discovered a weak relationship between the macroeconomic variables (external debt, inflation rate, fiscal deficit, exchange rate, foreign capital inflow, investment and industrial output) and average share price in Nigeria. The study revealed among others that the share prices are not influenced by the macroeconomic variables with the exception of an exchange rates which showed significant impact on the share prices.

Sulaiman and Ibrahim (2014) reviewed stock market development, foreign direct investment and macroeconomic stability using evidence from Nigerian stock market. Johensen co-integration and the error correction mechanism (ECM) techniques were used to examine the FDI impact on the level of development of the Nigerian stock market from 1981 to 2010. The result showed that FDI has a positive but insignificant effect while the exchange rate has a significant and negative relationship with the stock market performance.

Therefore, having looked at other scholars empirical study, FDI inflows and the volatile macroeconomic environment, the current study seeks to investigate the impact of FDI on the Nigerian stock market performance.

\section{Research Methodology}

The study area covers the federal Republic of Nigeria. The study focuses on the the impact of FDI on the stock market performances in Nigeria, (1985-2014). This study examines the impact of FDI on the stock market performances in Nigeria, (1985-2014). Here, the study highlights the methods and procedures that were used in collecting data, analysing them and testing of the hypothesis. The research method used in this study was survey of secondary data or quasi-experimental design.

The method mainly used in collection of data for this study was secondary information or data. The other sources of data are from official materials and workshop/seminar publication. The sources of data were from such areas as:

(i) International Monetary Fund (IMF) World Economic Outlook Database;

(ii) International Financial Statistics;

(iii) Nigerian Stock Exchange Bulletin;

(iv) CBN annual reports, Economic and Financial review;

(v) CBN bulletin;

(vi) National Bureaus of statistics.

Descriptive and inferential statistics were used to analyse the data for this study. In this study, percentages, ratios, frequency distribution and ordinary least square of multiple regressions were used to analyse the research questions and achieve the study objectives.

\subsection{Model Specification}

FDI = $\mathrm{f}($ RGDP, NSET, TBR, SPI, MS, CPI, RERI)

Where;

FDI $=$ Foreign Direct Investment

RGDP $=$ Real Gross Domestic Product

NSET $=$ Nigerian Stock Exchange Transactions

$\mathrm{TBR}=$ Treasury Bill Rate

SPI $=$ Share Price Index

MS $=$ Money Supply

CPI $=$ Consumer Price Index

RERI $=$ Real Effective Exchange Rate Index

\subsection{Mathematical Specification}

$\mathrm{Y}_{\mathrm{i}}=\mathrm{b}_{0}+\mathrm{b}_{1} \mathrm{X}_{1}+\mathrm{bX}_{2}+\mathrm{bX} \mathrm{X}_{3}+\mathrm{bX}_{4}+\mathrm{bX} \mathrm{X}_{5}+\mathrm{bX} \mathrm{X}_{6}+\mathrm{bX}+\mathrm{e}$

Where; 
$\mathrm{Y}_{\mathrm{i}}=$ Foreign Direct Investment

$\mathrm{X}_{1}=$ Real Gross Domestic Product

$\mathrm{X}_{2}=$ Nigerian Stock Exchange Transactions

$\mathrm{X}_{3}=$ Treasury Bill Rate

$\mathrm{X}_{4}=$ Share Price Index

$\mathrm{X}_{5}=$ Money Supply

$\mathrm{X}_{6}=$ Consumer Price Index

$\mathrm{X}_{7}=$ Real Effective Exchange Rate Index

$b_{0}=$ The parameter which represents the intercept

$b_{1}, b_{2}, b_{3}, b_{4}, b_{5}, b_{6}, b_{7}=$ The regression parameters used in determining the significance of the impact of each of the independent or explanatory variables $\mathrm{x}_{1}, \mathrm{x}_{2}, \mathrm{x}_{3}, \mathrm{x}_{4}, \mathrm{x}_{5}, \mathrm{x}_{6}, \mathrm{x}_{7}$ on dependent variable, $\mathrm{Y}_{\mathrm{i}}$.

$\mathrm{e}=$ Random disturbance term. These include the variables which (although not specified) in this model may also impact the stock market in Nigeria from 1985-2014. They include government policies, militants' disturbances, political instability etc.

\section{Results and Discussions}

The results of the regressions that answer the research questions and achieve the objectives of the study specified earlier in the study have been estimated in this section. The estimates are subjected to various statistical tests meant to address the research questions and achieve the research objectives. On the basis of the empirical findings provided by the results, the hypotheses of the study were tested.

\subsection{Data Presentation}

Table 1 shows the secondary data on FDI and Nigeria's selected economic and financial indicators (1985-2014). All the computations of the regression analysis in this study are based on these secondary data generated from Central Bank of Nigeria Statistical Bulletins.

Table 1. Foreign Direct Investment and Determinants of Stock Market Performance in Nigeria (1985-2014)

\begin{tabular}{|l|c|c|c|c|c|c|c|c|}
\hline Years & $\begin{array}{c}\text { Foreign } \\
\text { Direct } \\
\text { Investment } \\
\text { (FDI) } \%)\end{array}$ & $\begin{array}{c}\text { Real Gross } \\
\text { Domestic } \\
\text { Product } \\
\text { Annual } \\
\text { (RGDP) } \\
(\%)\end{array}$ & $\begin{array}{c}\text { Nigerian } \\
\text { Stock } \\
\text { Exchange } \\
\text { Transactions } \\
\text { (NSET) } \\
\text { N'million }\end{array}$ & $\begin{array}{c}\text { Treasur } \\
\text { y Bill } \\
\text { Rate } \\
(\text { TBR) } \\
(\%)\end{array}$ & $\begin{array}{c}\text { Share } \\
\text { Price } \\
\text { Index At } \\
\text { Year End } \\
\text { (SPI) }(\%)\end{array}$ & $\begin{array}{c}\text { Money } \\
\text { Supply } \\
\text { (M2) } \\
\text { N'billion } \\
(\text { MS) }\end{array}$ & $\begin{array}{c}\text { Consum } \\
\text { er Price } \\
\text { Index } \\
\text { (CPI) } \\
(\%)\end{array}$ & $\begin{array}{c}\text { Real } \\
\text { Effective } \\
\text { Exchange } \\
\text { Rate Index } \\
\text { (RERI) } \\
(\%)\end{array}$ \\
\hline 1985 & 1.68 & 8.32 & 316.6 & 8.50 & 127.3 & 22.30 & 0.83 & 490.41 \\
\hline 1986 & 0.93 & -8.75 & 497.9 & 8.50 & 163.8 & 23.81 & 0.88 & 266.90 \\
\hline 1987 & 2.53 & -10.75 & 382.4 & 11.75 & 190.9 & 27.57 & 0.98 & 85.17 \\
\hline 1988 & 1.63 & 7.54 & 850.3 & 11.75 & 233.6 & 38.36 & 1.51 & 85.57 \\
\hline 1989 & 7.78 & 6.47 & 610.3 & 17.50 & 325.3 & 45.90 & 2.27 & 76.18 \\
\hline 1990 & 1.91 & 12.77 & 225.4 & 17.50 & 513.8 & 52.86 & 2.44 & 70.80 \\
\hline 1991 & 2.60 & 2.21 & 242.1 & 15.00 & 783.0 & 75.40 & 2.75 & 59.95 \\
\hline 1992 & 3.06 & 3.21 & 491.7 & 21.00 & 1107.6 & 111.11 & 3.98 & 49.73 \\
\hline 1993 & 8.52 & 4.84 & 804.4 & 26.90 & 1543.8 & 165.34 & 6.26 & 54.50 \\
\hline 1994 & 10.83 & 3.55 & 985.9 & 12.50 & 2205.0 & 230.29 & 9.82 & 100.81 \\
\hline 1995 & 3.78 & 2.24 & 1838.8 & 12.50 & 5092.2 & 289.09 & 16.98 & 160.13 \\
\hline 1996 & 4.55 & 7.61 & 6979.6 & 12.25 & 6992.1 & 345.85 & 21.95 & 207.65 \\
\hline 1997 & 4.30 & 5.30 & 10330.5 & 12.00 & 6440.5 & 413.28 & 23.82 & 235.94 \\
\hline
\end{tabular}




\begin{tabular}{|l|l|l|l|l|l|l|l|c|}
\hline 1998 & 3.28 & 5.15 & 13571.1 & 12.95 & 5672.7 & 488.15 & 26.20 & 272.37 \\
\hline 1999 & 2.80 & 2.80 & 14072.0 & 17.00 & 5266.4 & 628.95 & 27.93 & 70.15 \\
\hline 2000 & 2.46 & 7.70 & 28153.1 & 12.00 & 8111.0 & 878.46 & 29.87 & 69.88 \\
\hline 2001 & 2.70 & 7.03 & 57683.8 & 12.95 & 10963.1 & 1269.32 & 35.51 & 77.84 \\
\hline 2002 & 3.17 & 6.90 & 59406.7 & 18.88 & 12137.7 & 1505.96 & 40.08 & 78.09 \\
\hline 2003 & 2.96 & 11.89 & 120402.6 & 15.02 & 20128.9 & 1952.92 & 45.70 & 73.20 \\
\hline 2004 & 2.13 & 8.79 & 225820.0 & 14.21 & 23844.5 & 2131.82 & 52.56 & 74.92 \\
\hline 2005 & 4.44 & 8.68 & 262935.8 & 7.00 & 24085.8 & 2637.91 & 61.95 & 85.55 \\
\hline 2006 & 3.34 & 8.33 & 470253.4 & 8.80 & 33189.3 & 3797.91 & 67.05 & 91.50 \\
\hline 2007 & 3.63 & 9.06 & 1076020.4 & 6.91 & 57990.2 & 5127.40 & 70.66 & 89.65 \\
\hline 2008 & 3.94 & 8.01 & 1679143.7 & 4.50 & 31450.8 & 8008.20 & 78.84 & 99.13 \\
\hline 2009 & 5.05 & 8.97 & 685717.3 & 6.13 & 20827.2 & 9411.11 & 87.94 & 92.15 \\
\hline 2010 & 1.64 & 9.97 & 799911.0 & 10.25 & 24770.5 & 11034.94 & 100.00 & 100.00 \\
\hline 2011 & 2.15 & 4.89 & 638925.7 & 16.75 & 20730.6 & 12172.49 & 110.84 & 99.64 \\
\hline 2012 & 1.53 & 4.28 & 808991.4 & 17.20 & 28078.8 & 13895.39 & 124.38 & 111.32 \\
\hline 2013 & 1.07 & 5.39 & 2350875.7 & 13.34 & 41329.2 & 15160.29 & 134.92 & 118.82 \\
\hline 2014 & N/A & 6.31 & 1334783.1 & 17.25 & 34657.2 & 17680.52 & 145.80 & 128.36 \\
\hline
\end{tabular}

Sources: Central Bank of Nigeria, NSE Bulletin, International Monetary Fund World Economic Outlook Database, International Financial Statistics and Data Files (2015).

\subsection{Presentation of Regression Results}

The summary of FDI regression result from the Two - Stage Least Squares Analysis is as shown in the model summary in Table 4.2. The table presents the results of the empirical regression estimates for the specified equation in the model.

Table 2. Summary of the Results

\begin{tabular}{|l|l|l|}
\hline $\mathrm{R}$ & $=$ & 0.390 \\
\hline $\mathrm{R}^{2}$ & $=$ & 0.152 \\
\hline Adj. $\mathrm{R}$ & $=$ & -0.130 \\
\hline Std Error of estimate & $=$ & 2.37774 \\
\hline Durbin - Watson & $=$ & 1.608 \\
\hline F Value & $=$ & 0.539 \\
\hline DF & $=$ & $29(1-)-7=21$ i.e. F-tab $=2.49$ \\
Level of Significance & & 0.796
\end{tabular}

The coefficient of correlation $\mathrm{R}$ and Coefficient of determination $\mathrm{R}^{2}$ measure the explanatory power of the multiple regression model. From the results, there is a low coefficient of correlation $(15.20 \%)$ between the independent and the dependent variables. The implication is that the variables in the equation are not very useful for explaining the level of the performance of FDI on stock or capital market that has occurred between1985 - 2014. There is also a very low significant coefficient of determination (39\%). The standard error of the estimates also known as residual standard deviation has a value of 2.37774. The F- statistic value is found to be 0.539 . The $\mathrm{F}$ value is very insignificant at the 5 percent level. The overall fit of the regression model measured by the F- statistic, is statistically insignificant at this level. The Durbin Watson (DW) statistic of 1.608 indicates that there is problem of serial correlation in the regression model. This is a case of positive serial non-correlation. Also, multi-collinearity which often presents in cross-sectional data seems to be nonexistent in the model. In Table 4.3 the estimation results using the seven explanatory variables are presented at alpha equal to 0.05 level of significance. 
Table 4.3 Estimation Results with Minor Interpretations

\begin{tabular}{|c|c|c|c|c|c|c|}
\hline Variable & Means & $\begin{array}{l}\text { Standard } \\
\text { Deviation }\end{array}$ & $\begin{array}{l}\text { Estimated } \\
\text { Coefficient }\end{array}$ & T Stat & $\mathrm{T}-\mathrm{Tab}$ & Remarks \\
\hline $\mathrm{Y}_{\mathrm{i}} \quad \mathrm{FDI}$ & 3.4617 & 2.23639 & 2.376 & 1.715 & & \\
\hline $\begin{array}{l}\mathrm{X}_{2} \text { Nigerian Stock } \\
\text { Exchange Transactions }\end{array}$ & 321256.537 & 568447.4642 & 0.000 & 0.221 & $<2.49$ & Not Significant \\
\hline $\mathrm{X}_{4} \quad$ Share Price Index & 13596.4000 & 14807.25969 & 0.000 & -0.027 & $<2.49$ & Not Significant \\
\hline $\mathrm{X}_{5}$ Money Supply (M2) & 3170.4269 & 4689.86765 & 0.000 & -0.086 & $<2.49$ & Not Significant \\
\hline $\mathrm{X}_{6}$ Consumer Price Index & 40.9966 & 40.56896 & 0.062 & -0.294 & $<2.49$ & Not Significant \\
\hline $\mathrm{X}_{7}$ Exchange Rate & 122.3431 & 93.02330 & 0.006 & -0.891 & $<2.49$ & Not Significant \\
\hline
\end{tabular}

$\mathrm{T}$ values at 5 percent $\mathrm{n}-2 \mathrm{DF}=2.093 \mathrm{~T}$ values at 10 percent $\mathrm{n}-2 \mathrm{DF}=1.725 *$ Significant at $10 \%$ level $* *$ Significant at $5 \%$ level

The study found that Real Gross Domestic Products $(0.604<2.49)$, Nigerian Stock Exchange Transactions $(0.221<$ 2.49), Treasury Bills $(0.274<2.49)$, Share Price Index $(-0.027<2.49)$, Money Supply $(-0.086<2.49)$, Consumer Price Index $(-0.294<2.49)$ and Exchange Rate $(-0.891<2.49)$ have not shown appreciable and useful items as explanatory variables under estimations with foreign direct investment because all remained insignificant at the end of the estimation. The t- test results confirm the trend of the analysis as indicated here. Here, the process of affection or correlation in the system is not efficient.

a) The Extent to which FDI Affects the Economic Growth in Nigeria

The results of the study show that in effect, a positive and / insignificant relationship exists between FDI and Real Gross Domestic Products $(0.604<2.49)$.

b) The Extent to which Nigerian Stock Exchange Transactions, Treasury Bills, Share Price Index have been Affected by FDI in Nigeria

The results of the study show that in effect, a positive but insignificant relationship exists between FDI and Nigerian Stock Exchange Transactions $(0.221<2.49)$, Treasury Bills $(0.274<2.49)$, while the relationship between FDI and Share Price Index $(-0.027<2.49)$ indicate negative and insignificant outcome. However, FDI has not influenced the performance of the capital market variables because the study revealed correlation coefficients of $-0.215,0.195$ and -0.191 respectively. The implication of this is that the dominance of the financial sector in Nigeria by commercial banks means that they must play a central role in financing the sustainable growth of the capital market and private sector in Nigeria.

c) The Extent to which Money Supply (M2) has been Affected by FDI

The empirical analysis revealed that FDI has a negative (8.6\%) effect on money supply/ capital market. In essence deficit changes in broad money drive inflation in Nigeria in the long run, effect on CPI, inflation expectations and weather which affect the market both in short and in the short run. This special characteristic of the interest rate in Nigeria may be clearly understood when the activities in capital market are taken into consideration. The two main impacts of inflation on capital market are a direct impact (through the erosion of purchasing power of stakeholders) and an indirect impact (through the erosion of the businesses own purchasing power). The study found that to a large extent FDI has not been able to reduce inflation in Nigeria.

\section{d) The Extent to which FDI Affect the Prices of Goods and Services in Nigeria}

The empirical analysis revealed that FDI has negative (29.48\%) effect on prices of goods and services in Nigeria in the long run, effect on CPI and inflation expectations and weather significantly inflation affect the market both in short and in the short run. Prime lending rate was found to be a significant determinant of inflation in both the short run and the long run. This special characteristic of the interest rate in Nigeria may be clearly understood when the activities in capital market are taken into consideration. The two main impacts of inflation on capital market are a direct impact (through the erosion of purchasing power of stakeholders) and an indirect impact (through the erosion of the businesses own purchasing power).

e) The Extent to which FDI has affected the Exchange Rate in Nigeria

The results of the study show that in effect, a negative and / insignificant relationship exists between FDI and the 
Exchange Rate in Nigeria $(-0.891<2.49)$.

\subsection{Analysis and Test of Hypotheses}

The study has earlier stated the following hypotheses:

$\mathrm{Ho}_{1}$ : There is no significant relationship between the FDI and the economic growth in Nigeria.

$\mathrm{Ho}_{2}$ : No significant relationship exists between the FDI and Nigerian Stock Exchange Transactions.

$\mathrm{Ho}_{3}$ : No significant relationship exists between the FDI and the Treasury Bills.

$\mathrm{Ho}_{4}$ : There is no significant relationship between the FDI and Share Price Index.

$\mathrm{Ho}_{5}$ : No relationship exists between Money supply (M2) and FDI.

$\mathrm{Ho}_{6}$ : There is no relationship between FDI and the prices of goods and services.

$\mathrm{Ho}_{7}$ : No tangible relationship between Exchange Rate and FDI.

The estimation / model is statistically insignificant as the $\mathrm{f}$ - statistic value is 0.539 against table value of 2.49

Decision Rule: Based on the facts that have emerged out of the estimations the study has accepted all the null hypotheses thus: There is no significant relationship between the FDI and the economic growth in Nigeria, no significant relationship exists between the FDI and Nigerian Stock Exchange Transactions, no significant relationship exists between the FDI and the Treasury Bills, there is no significant relationship between the FDI and Share Price Index, no relationship exists between Money supply (M2) and FDI, there is no relationship between FDI and the prices of goods and services and no tangible relationship between Exchange Rate and FDI from 1985-2014.

\section{Conclusion and Recommendations}

The main objective of this study is to investigate the impact of FDI on Nigerian stock market performances from 1985 to 2014. The results revealed that FDI has an insignificant impact on the economy and the macroeconomic variables that determine stock market performances. Thus, the paper recommends policies that would encourage foreign firms operating in the oil and gas including the telecommunication and the agricultural sectors to be listed since it would go a long way in attracting more FDI, leading to improvement in the stock market performances. This should be complemented with policies that ensure stable macroeconomic environment. Finally, future research can employ additional variables, different estimation techniques to investigate on the stock market performances.

\section{References}

Abel, E. E., \& Nikki, C. (2011). FDI flows to Sub- Saharan Africa: the impact of finance, institution and natural resource endowment, Department of Economics and Economic History, Rhodes University, Graham's town, South Africa.

Adam, A. M., \& Tweneboah, G. (2008). Macroeconomic factors and stock market movement: Evidence from Ghana.

Aliber, R. Z. (1970). "A theory of direct foreign investment", in C.P. Kindleberger (ed.), the international corporation. MIT Press, Cambridge, MA, United States.

Asaolu, T. O., \& Ogunmuyiwa, M. S. (2011). An econometric analysis of the impact of macroeconomic variables on stock market movement in Nigeria. Asian journal of business management, 3(1), 72-78.

Buckley, P. J., \& Casson, M. (1976). The future of multinational enterprises. Macmillan London.

Corrado, C. J., \& Jordan, B. D. (2002). The Fundamentals of Investments Valuation and Management. $2^{\text {nd }}$ edition USA, McGraw-Hill Companies Inc.

Central Bank of Nigeria (2015). www.trading economics.com.

Economy watch, www.economy watch.com/stock_markets_in_world/performance.html. Farlex Financial Dictionary, (2012).

International Monetary Fund (2015). International Financial Statistics 2015, Online Version, Washington: International Monetary Fund. Investopedia, www.investopedia.com

Kindleberger, C. P. (1969). American Business Abroad. Yale University Press, New Haven, CT, United States. National bureau of statistics, www.trading economics. com

Okwuchukwu, O. (2015). Exchange rate volatility, stock market performance and foreign direct investment in Nigeria. HRMARS, 5(2).

Oseni, I. O., \& Enilolobo, O. S. (2011). Effect of foreign direct investment and stock market development on economic growth in Nigeria (1980-2009). European Journal of Business and Management, 3(12). 
Sulaiman, U. M., \& Ibrahim M. (2014). Stock market development, FDI and macro-economic stability: Evidence from Nigeria.

Vernon, R. (1966). International investment and international trade in the product cycle, Quarterly Journal of Economics, 80, $190-207$.

\section{Appendix I}

Foreign Direct Investment And Determinants Of Stock Market Performance In Nigeria.

\begin{tabular}{|c|c|c|c|c|c|c|c|c|}
\hline $\begin{array}{l}\text { YEAR } \\
S\end{array}$ & $\begin{array}{c}\text { FOREIGN } \\
\text { DIRECT } \\
\text { INVESTME } \\
\text { NT (FDI) } \\
(\%)\end{array}$ & $\begin{array}{c}\text { NIGERIAN } \\
\text { STOCK } \\
\text { EXCHANGE } \\
\text { TRANSACTI } \\
\text { ONS (NSET) } \\
\text { N'MILLION }\end{array}$ & $\begin{array}{c}\text { TREAS } \\
\text { URY } \\
\text { BILL } \\
\text { RATE } \\
\text { (TBR) } \\
(\%)\end{array}$ & $\begin{array}{l}\text { SHARE } \\
\text { PRICE } \\
\text { INDEX AT } \\
\text { YEAR } \\
\text { END (SPI) } \\
(\%)\end{array}$ & $\begin{array}{c}\text { MONEY } \\
\text { SUPPLY } \\
\text { (M2) } \\
\text { N'BILLION }\end{array}$ & $\begin{array}{c}\text { CONSU } \\
\text { MER } \\
\text { PRICE } \\
\text { INDEX } \\
(\mathrm{CPI}) \\
(\%)\end{array}$ & $\begin{array}{c}\text { REAL } \\
\text { EFFECTIV } \\
\text { E } \\
\text { EXCHANG } \\
\text { E RATE } \\
\text { INDEX } \\
(\text { REXCH) } \\
(\%)\end{array}$ & $\begin{array}{c}\text { REAL } \\
\text { GROSS } \\
\text { DOMESTI } \\
\text { C } \\
\text { PRODUC } \\
\text { T } \\
\text { ANNUAL } \\
\text { (RGDP) } \\
(\%)\end{array}$ \\
\hline 1985 & 1.68 & 316.6 & 8.50 & 127.3 & 22.30 & 0.83 & 490.41 & 8.32 \\
\hline 1986 & 0.93 & 497.9 & 8.50 & 163.8 & 23.81 & 0.88 & 266.90 & -8.75 \\
\hline 1987 & 2.53 & 382.4 & 11.75 & 190.9 & 27.57 & 0.98 & 85.17 & -10.75 \\
\hline 1988 & 1.63 & 850.3 & 11.75 & 233.6 & 38.36 & 1.51 & 85.57 & 7.54 \\
\hline 1989 & 7.78 & 610.3 & 17.50 & 325.3 & 45.90 & 2.27 & 76.18 & 6.47 \\
\hline 1990 & 1.91 & 225.4 & 17.50 & 513.8 & 52.86 & 2.44 & 70.80 & 12.77 \\
\hline 1991 & 2.60 & 242.1 & 15.00 & 783.0 & 75.40 & 2.75 & 59.95 & 2.21 \\
\hline 1992 & 3.06 & 491.7 & 21.00 & $1,107.6$ & 111.11 & 3.98 & 49.73 & 3.21 \\
\hline 1993 & 8.52 & 804.4 & 26.90 & $1,543.8$ & 165.34 & 6.26 & 54.50 & 4.84 \\
\hline 1994 & 10.83 & 985.9 & 12.50 & $2,205.0$ & 230.29 & 9.82 & 100.81 & 3.55 \\
\hline 1995 & 3.78 & $1,838.8$ & 12.50 & $5,092.2$ & 289.09 & 16.98 & 160.13 & 2.24 \\
\hline 1996 & 4.55 & $6,979.6$ & 12.25 & $6,992.1$ & 345.85 & 21.95 & 207.65 & 7.61 \\
\hline 1997 & 4.30 & $10,330.5$ & 12.00 & $6,440.5$ & 413.28 & 23.82 & 235.94 & 5.30 \\
\hline 1998 & 3.28 & $13,571.1$ & 12.95 & $5,672.7$ & 488.15 & 26.20 & 272.37 & 5.15 \\
\hline 1999 & 2.80 & $14,072.0$ & 17.00 & $5,266.4$ & 628.95 & 27.93 & 70.15 & 2.80 \\
\hline 2000 & 2.46 & $28,153.1$ & 12.00 & $8,111.0$ & 878.46 & 29.87 & 69.88 & 7.70 \\
\hline 2001 & 2.70 & $57,683.8$ & 12.95 & $10,963.1$ & $1,269.32$ & 35.51 & 77.84 & 7.03 \\
\hline 2002 & 3.17 & $59,406.7$ & 18.88 & $12,137.7$ & $1,505.96$ & 40.08 & 78.09 & 6.90 \\
\hline 2003 & 2.96 & $120,402.6$ & 15.02 & $20,128.9$ & $1,952.92$ & 45.70 & 73.20 & 11.89 \\
\hline 2004 & 2.13 & $225,820.0$ & 14.21 & $23,844.5$ & $2,131.82$ & 52.56 & 74.92 & 8.79 \\
\hline 2005 & 4.44 & $262,935.8$ & 7.00 & $24,085.8$ & $2,637.91$ & 61.95 & 85.55 & 8.68 \\
\hline 2006 & 3.34 & $470,253.4$ & 8.80 & $33,189.3$ & $3,797.91$ & 67.05 & 91.50 & 8.33 \\
\hline 2007 & 3.63 & $1,076,020.4$ & 6.91 & $57,990.2$ & $5,127.40$ & 70.66 & 89.65 & 9.06 \\
\hline 2008 & 3.94 & $1,679,143.7$ & 4.50 & $31,450.8$ & $8,008.20$ & 78.84 & 99.13 & 8.01 \\
\hline 2009 & 5.05 & $685,717.3$ & 6.13 & $20,827.2$ & $9,411.11$ & 87.94 & 92.15 & 8.97 \\
\hline
\end{tabular}




\begin{tabular}{|l|l|l|l|l|l|l|l|l|}
\hline 2010 & 1.64 & $799,911.0$ & 10.25 & $24,770.5$ & $11,034.94$ & 100.00 & 100.00 & 9.97 \\
\hline 2011 & 2.15 & $638,925.7$ & 16.75 & $20,730.6$ & $12,172.49$ & 110.84 & 99.64 & 4.89 \\
\hline 2012 & 1.53 & $808,991.4$ & 17.20 & $28,078.8$ & $13,895.39$ & 124.38 & 111.32 & 4.28 \\
\hline 2013 & 1.07 & $2,350,875.7$ & 13.34 & $41,329.2$ & $15,160.29$ & 134.92 & 118.82 & 5.39 \\
\hline 2014 & N/A & $1,334,783.1$ & 17.25 & $34,657.2$ & $17,680.52$ & 145.80 & 128.36 & 6.31 \\
\hline
\end{tabular}

Sources: Central Bank Of Nigeria, Nse Bulletine, International Monetary Fund, World Economic Outlook Database, International Financial Statistics And Data Files (2015).

\section{Appendix II}

NIGERIA CONSUMER PRICE INDEX (CPI)

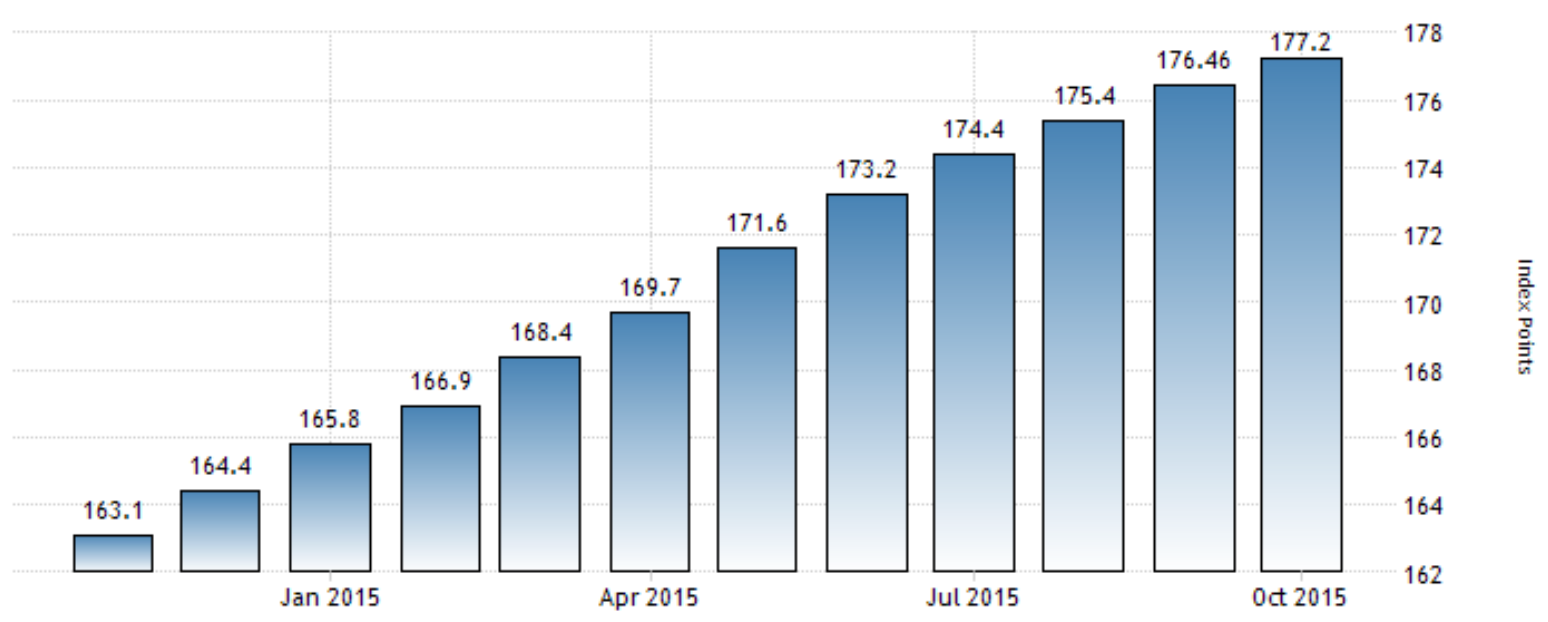

SOURCE: WWW.TRADINGECONOMICS.COM I NATIONAL BUREAU OF STATISTICS, NIGERIA

Consumer Price Index 


\section{Appendix III}

Real effective exchange rate index $(2000=100)$ in Nigeria

Real effective exchange rate index $(2000=100)$ in Nigeria was last measured at 128.36 in 2014 , according to the World

Bank. Real effective exchange rate is the nominal effective exchange rate (a measure of the value of a currency against a weighted average of several foreign currencies) divided by a price deflator or index of costs. This page has the latest recorded value, an historical data chart and related indicators for Real effective exchange rate index $(2000=100)$ in Nigeria.

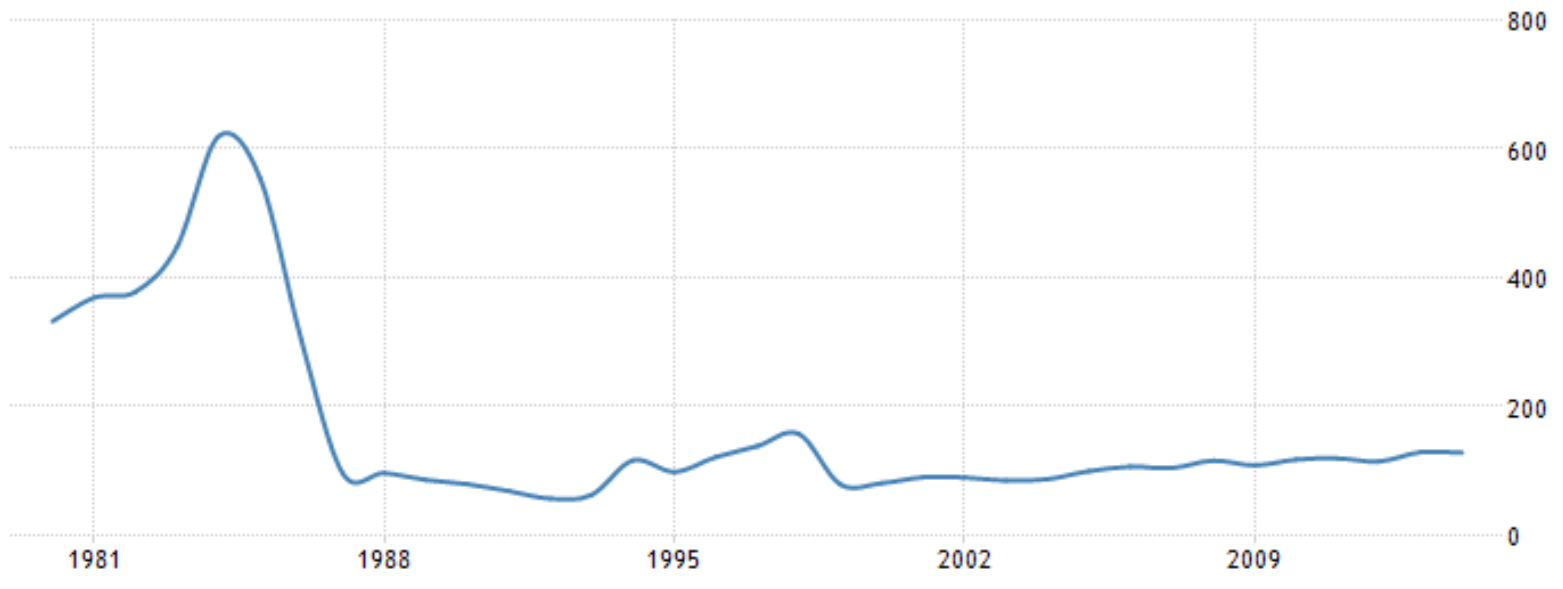

World Bank Indicators - Nigeria - Exchange rates \& prices

\section{NIGERIA MONEY SUPPLY M2}

\section{NIGERIA MONEY SUPPLYM2}

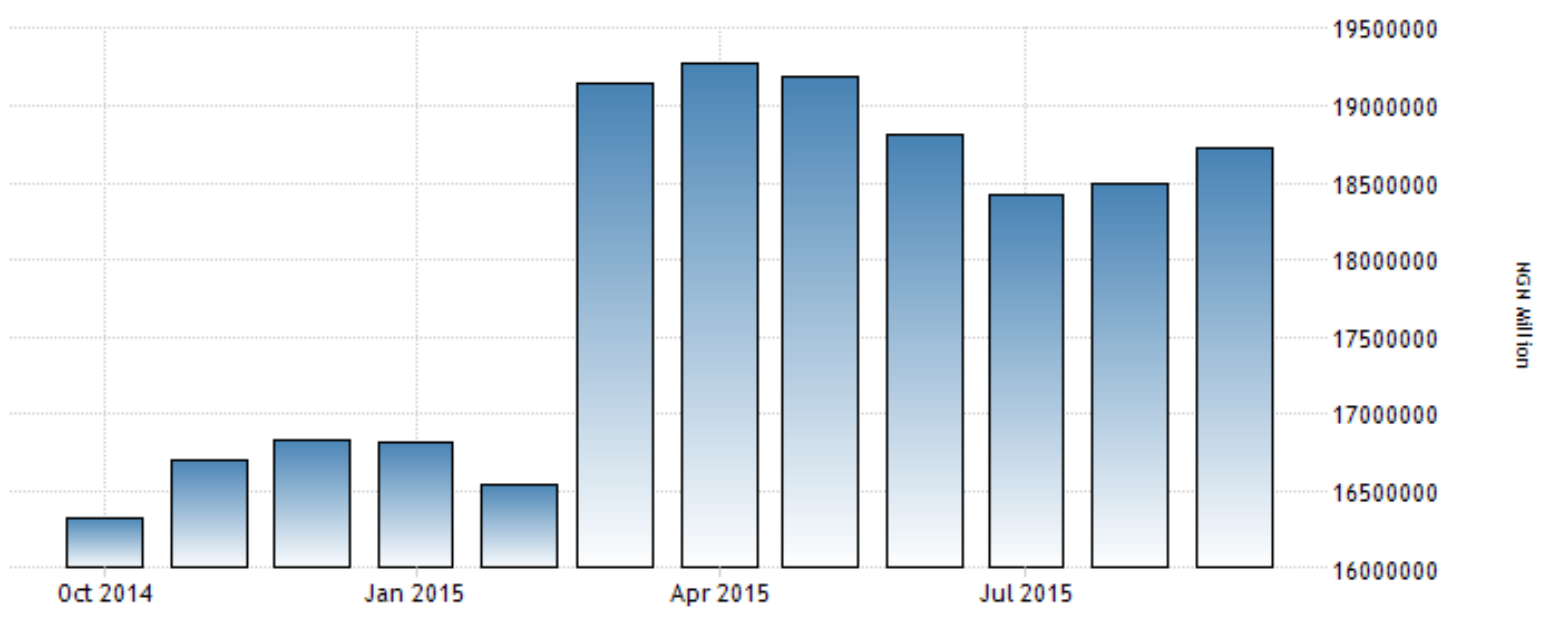




\section{Appendix IV}

Nigeria Foreign Direct Investment 2007-2015 | Data | Chart | Calendar

Foreign Direct Investment in Nigeria increased by 624.87 USD Million in the second quarter of 2015. Foreign Direct Investment in Nigeria averaged 1410.46 USD Million from 2007 until 2015, reaching an all-time high of 3084.90 USD Million in the fourth quarter of 2012 and a record low of 624.87 USD Million in the second quarter of 2015. Foreign Direct Investment in Nigeria is reported by the Central Bank of Nigeria.

\section{NIGERIAN FOREIGN DIRECT INVESTMENT}

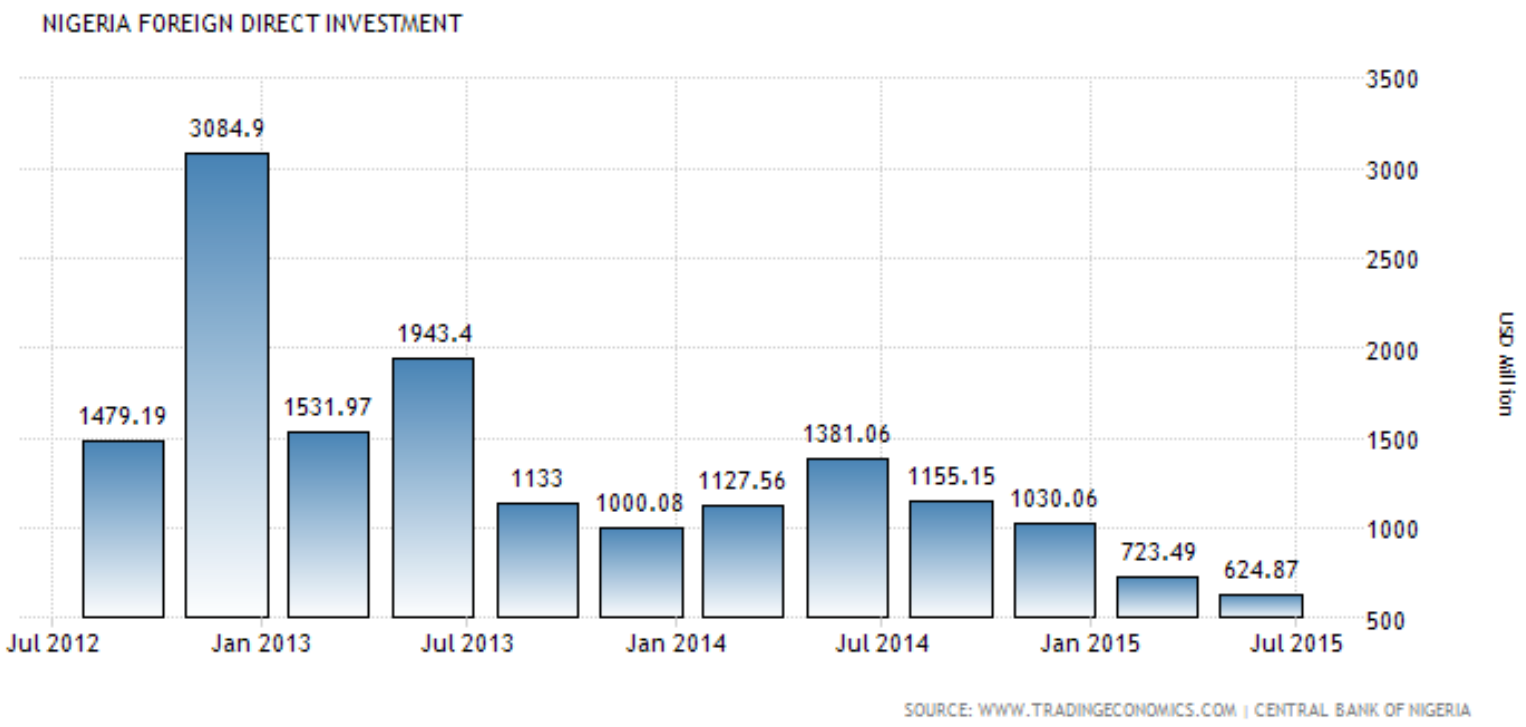

\section{Copyrights}

Copyright for this article is retained by the author(s), with first publication rights granted to the journal.

This is an open-access article distributed under the terms and conditions of the Creative Commons Attribution license which permits unrestricted use, distribution, and reproduction in any medium, provided the original work is properly cited. 